\title{
ANALISIS PEMASARAN BUAH MANGGIS \\ DIKECAMATAN TEMBILAHAN HULU KABUPATEN INDRAGIRI HILIR
}

\author{
Fitriana \\ Mahasiswa Program Studi Agribisnis Fakultas Pertanian UNISI \\ Email : fitri_ana@yahoo.co.id
}

\begin{abstract}
ABSTRAK
Tujuan penelitian ini adalah : (1) untuk mengetahui saluran pemasaran buah manggis di Kecamatan Tembilahan Hulu. (2) untuk mengetahui margin pemasaran, fharmer's share dan profit marjin pada setiap saluran pemasaran (3) untuk mengetahui efisiensi pemasaran buah manggis Kecamatan Tembilahan Hulu. Data dikumpulkan melalui survey dan wawancara. Penentuan sampel petani dilakukan dengan metode random sampling, sedangkan untuk penentuan sampel pedagang menggunakan metode snowball sampling. Metode analisis data yang digunakan adalah margin pemasaran, analisis fharmer's share,profit margin dan efisiensi pemasaran. Hasil penelitian ini menjukan bahwa (1) saluran pemasaran buah manggis Kecamatan Tembilahan Hulu yaitu saluran I (Petanikonsumen) saluran II (petani- Pedagang Pengecer) saluran III (Petnai-Pedagang Pengumpul- Pedagang pengecer-konsumen).(2) a. pada saluran I tidak terdapat margin pemasaran, saluran II dan III masing-masing Rp.9,000.00/kg dan Rp.18,016.67/kg. b. Fharmer's share masing-masing saluran I (100\%), Saluran II $(37.50 \%)$ dan saluran III $(22.80 \%)$. c. Profit marjin terbesar pada pedagang pengecer saluran II $(92.68 \%)$, sedangkan profit margin pedagang pengecer saluran III (92.09\%) dan Pedagang pengupul sebesar (89.77\%). (3) Efisiensi pemasaran Ep masing-masing saluran pemasaran I (5.39\%) saluran II (7.32\%) dan saluran III $(7.90 \%)$.
\end{abstract}

Kata Kunci : Manggis, Saluran Pemasaran, Efisiensi

\section{PENDAHULUAN}

Saptana et.al (2010), menyatakan bahwa komoditas hortikultura merupakan komoditas potensial yang mempunyai nilai ekonomi tinggi dan memiliki potensi untuk terus dikembangkan. Salah satu komoditas hortikultura yang prospektif untuk dikembangkan di Indonesia adalah manggis.

Pemerintah telah menetapkan manggis sebagai komoditas unggulan nasional dalam RUSNAS Buah
(Riset Unggulan Strategis Nasional Buah) sejak tahun 2000. Hal tersebut dikarenakan manggis memiliki potensi untuk terus dikembangkan. Pemerintah berusaha untuk memperbaiki teknologi produksi di tingkat petani dan menemukan varietas unggul dengan produktivitas yang optimal (Direktorat Budidaya Tanaman Buah 2009).

Salah satu komoditas unggulan buah-buahan yang khas dari Kabupaten Indragiri Hilir adalah buah manggis Tembilahan. 
Keistimewaan buah manggis tembilahan dibandingkan dengan buah manggis lainnya yaitu selaian bentuk buahnya yang agak pipih, buah manggis tembilahan juga mempunyai rasa lebih manis dan sedikit masam (manis segar) di bangingkan buah manggis pada umumnya. Disamping itu daging buah lebih padat dan kadar airnya lebih rendah dari rata-rata kadar air pada manggis pada umumnya. (Balai Penelitian Tanaman Buah Solok.2003)

Kecamatan Tembilahan Hulu merupakan Kecamatan yang memiliki luas lahan terbesar kedua setelah Kecamatan GAS di Kabupaten Indragiri Hilir hanya saja walaupun memiliki luas wilayah yang cukup besar akan tetapi produktivitasnya masih kecil ini artinya buah manggis di Kecamatan Tembilahan Hulu belum berproduksi secara maksimal.

Masyarakat di Kecamatan Tembialahan Hulu biasanya memasarkan buah manggis dengan beberapa cara yaitu pertama dengan menjual langsung kepada konsumen, kedua dengan menjual kepada pedagang pengecer dan yang ketiga yaitu dengan menjual kepada pedagang pengumpul yang akan memasarkan manggis tersebut keluar daerah.

Pemasaran merupakan faktor yang sangat penting dalam dunia usaha, tanpa adanya suatu pemasaran maka pendistribusian produksi hasil olahan maupun pertanian akan terhambat atau tidak sampai pada konsumen ataupun sasaran yang dituju. Untuk itulah pemasaran sangat penting untuk mewujudkan pembangunan pertanian di Indonesia.
Aspek pemasaran memang penting bila mekanisme pemasaran berjalan baik, maka semua pihak yang terlibat akan diuntungkan. Oleh karena itu peranan lembaga pemasaran yang biasanya terdiri dari produsen, tengkulak, pedagang pengumpul, eksportir atau lainnya menjadi amat penting.

Kondisi umum pada pemasaran produk pertanian adalah harga tinggi di konsumen namun petani hanya menerima bagian harga relative kecil. Harga buah manggis di tingkat petani hanya berkisar Rp. $5,000.00$ per $\mathrm{kg}$ samapai Rp.8,000.00 per kg sedangkan harga jual tingkat pedagang pengecer bisa mencapai Rp. 20,000.00 per kg. Hal tersebut dapat diindikasikan bahwa kurangnya efisienisi dari saluran pemasaran buah manggis.

Saluran

pemasaran

menggambarkan proses pendistribusian buah manggis dari petani ke konsumen. Hal terpenting dalam pemasaran produk pertanian adalah konsisrtensi masing-masing pihak dalam menjalankan fungsinya dan pembagian ilmbalan secara adil. Masalah pokok dalam pemasaran buah manggis adalah harga rendah ditingkat petani. Petani memiliki posisi tawar yang lemah dalam penentuan harga jual buah manggis sehingga pendapatan petani lebih rendah dari lemabaga pemasaran. Kondisi tersebut diakiatkan atas kurangnya efisiensinya saluran pemasaran. Tujuan penelitian adalah untuk mengetahui sistem pemasaran manggis di Kecamatan Tembilahan Hulu.

\section{TINJAUAN PUSTAKA}

2.1. Manggis

Manggis merupakan tanaman buah tropis yang asal usulnya tidak 
disebutkan secara pasti. Satu kepustakaan menyebutkan bahwa tanaman manggis berasal dari Malaysia, hal ini dinyatakan oleh Steenis pada tahun 1949. Sumber lain juga menyebutkan bahwa tanaman manggis berasal dari Semenanjung Malaya. Perdagangan dimasa lalu menyebabkan tanaman manggis menyebar dari satu benua kebenua lain, dari satu daerah kedaerah lain, dari Malaysia, keIndonesia, terus kePhilipina, Vietnam, Thailand, Burma dan Srilanka.

Pada sekitar tahun 1925, sebuah perusahaan besar bernama The United Fruit Coy di Honduras membudidayakan tanaman manggis secara besar-besaran yang bersifat komersial dalam bentuk perkebunan. Hasil budidaya manggis tersebut diperdagangkan oleh perusahaan tersebut dan membawa kesejahteraan bagi masyarakatnya. Kini tanaman manggis sudah menyebar dan dibudidayakan antara lain di Myanmar, Indonesia, cina, Australia, dan Amerika Tengah. DiIndonesia sendiri, tanaman manggis terdapat dihampir semua provinsi, dari barat sampai keujung timur, dari Sabang sampai Merauke.

\subsection{Pemasaran}

Pemasaran merupakan salah satu kegiatan pokok pengusaha dalam mempertahankan kelangsungan usahanya baik dalam pengembangan usaha maupun peningkatan laba. Pemasaran didefinisikan sebagai suatu sistem keseluruhan dari kegiatan bisnis, bertujuan untuk merencanakan, menentukan harga, mempromosikan, mendistribusikan barang dan jasa serta memuaskan kebutuhan konsumen (Stanton,1986)
Produksi dan pemasaran mempunyai keterkaitan erat. Peningkatan produksi tidak akan berarti, jika tidak ada dukungan sistem pemasaran dan mampu menyerap hasil produksi tersebut pada tingkat harga layak. Pemasaran merupakan proses penyampaian komoditas dari produsen ke konsumen melalui saluran pemasaran tertentu dan penyesuaian aktivitas dengan barang tersebut (Winardi, 1989).

\subsubsection{Saluran Pemasaran}

Saluran

pemasaran merupakan jalur dari lembagalembaga penyalur yang mempunyai kegiatan meyalurkan barang dari produsen kekonsumen. Penyalur ini secara aktif akan mengusahakan perpindahan bukan hanya secara fisik tapi dalam arti agar barang-barang tersebut dapat dibeli konsumen (Stanton, 1993).

Saluran distribusi atau saluran pemasaran merupakan suatu alur yang dilalui oleh arus barangbarang dari produsen keperantara dan akhirnya sampai pada pemakai. Saluran pemasaran merupakan suatu struktur unit organisasi dalam perusahaan dan luar perusahaan yang terdiri atas agen, dealer, pedagang besar, pengecer, melalui mana sebuah komoditi, produk atau jasa dipasarkan (Swasthadan Handoko, 1997).

Winardi

mengemukakan, lembaga-lembaga pemasaran dalam melaksanakan kegiatannya membentuk saluran atau pola pemasaran. Jenis saluran pemasaran dipilih berdasarkan beberapa pertimbangan, seperti daya serap pasar, selera konsumen dan sifat buah. Saluran pemasaran buahbuahan di Indonesia terdiri dari lima 
jenis. Kelima jenis saluran pemasaran tersebut antara lain :

1. Saluran I Petani Konsumen

2. Saluran II Petani Pedagang Pengecer Konsumen

3. Saluran III Petani Pedagang Besar Pedagang Pengecer Konsumen

4. Saluran IV Petani Pedagang Pengumpul Pedagang Pengecer Konsumen.

5. Saluran V Petani Pedagang Pengumpul Pedagang Besar Pedagang Pengecer

Konsumen.

\subsubsection{Biaya Pemasaran}

Secara umum biaya merupakan pengorbanan yang dikeluarkan oleh produsen dalam mengelola usaha taninya untuk mendapatkan hasil yang maksimal. Biaya merupakan pengorbanan yang diukur untuk suatu alat tukar berupa uang yang dilakukan untuk mencapai tujuan tertentu dalam usahataninya.

Biaya pemasaran merupakan biaya yang dikeluarkan untuk kegiatan atau aktifitas usaha pemasaran komoditas pertanian. Biaya pemasaran komoditas pertanian meliputi biaya transportasi/biaya angkut, biaya pungutan retribusi, biaya penyusutan dan lain-lain. Besarnya biaya pemasaran berbeda satu samalain. Hal ini disebabkan lokasi pemasaran, lembaga pemasaran (pengumpul, pedagang besar, pengecer dan sebagainya) dan efektifitas pemasaran yang dilakukan serta macam komoditas (Rahim dan Hastuti, 2007).

\subsubsection{Margin Pemasaran}

Marjin pemasaran adalah perbedaan harga dari petani dengan harga untuk konsumen. Harga di tingkat konsumen merupakan harga di tingkat petani, ditambah dengan seluruh biaya pemasaran dan keuntungan lembaga pemasaran. Metode perhitungan marjin pemasaran dapat ditempuh dengan dua cara, antara lain (Roziah, 2005):

1. Menghitung selisih harga jual di tingkat produsen dengan harga beli di tingkat konsumen akhir

2. Mengitung total biaya pemasaran dan keuntungan seluruh lembaga pemasaran.

\subsubsection{Farmer's Share}

Farmer's share adalah perbandingan antara harga yang diterima petani dengan harga yang dibayar oleh konsumen. Bagian yang diterima oleh petani dipengaruhi oleh jarak yang memisahkan konsumen akhir dari produsen yang akan mempengaruhi harga ditingkat petani. Dikarenakan biaya angkutan dan penjualan barang dibebankan kepada produsen dan konsumen. Umumnya bagian yang diterima petani akan semakin kecil jika julmlah tingkat pedagang perantara bertambah panjang dalam satu pemasaran (Limbong dan Sitorus, 1995)

\subsubsection{Efisiensi Pemasaran}

Efisiensi pemasaran menurut Soekartawi (2002) adalah persentase antara biaya pemasaran dengan nilai produk yang dipasarkan. Pemasaran tidakakan efisien jika biaya pemasaran semakin besar dan nilai produk yang dipasarkan jumlahnya tidak terlalu besar.

Sistem pemasaran dianggap
efisien apabila mampu
menyampaikan hasil-hasil dari
produsen kepada konsumen dengan


biaya murah dan mampu mengadakan pembagian yang adil dari keseluruhan harga yang dibayar konsumen terakhir kepada semua pihak yang ikut serta dalam kegiatan produksi dan pemasaran barang tersebut (Mubyarto,1995). Pemasaran dianggap efisien bila memenuhi dua syarat yaitu: (1) mampu menyampaikan hasil produksi dari produsen kepadakonsumen dengan biaya yang semurah-murahnya dan (2) mampu mengadakan pembagian yang adil dari keseluruhan hargayang dibayarkan konsumen akhir kepada semua pihak yang terkait dalam kegiatan pemasaran tersebut (Mubyarto, 1979).

\section{METODOLOGI PENELITIAN}

\subsection{Tempat dan Waktu \\ Penelitian}

Penelitian ini dilakukan di Kelurahan Tembilahan Barat dan Desa Pulau Palas Kecamatan Tembilahan Hulu Kabupaten Indragiri Hilir selama 3 bulan mulai dari April sampai dengan Juni 2017. Penentuan daerah penelitian secara Purposive Sampling berdasarakan salah satu sentra produksi manggis di KecamatanTembilahan Hulu

\subsection{Jenis dan Sumber Data}

Jenis dan sumber data yang digunakan dalam penelitian ini adalah :

1. Data primer

Data primer adalah data yang diperoleh langsung dari petani dan pedagang melalui wawancara dengan menggunakan daftar pertanyaan atau kuisioner yang telah disusun. Sumber data dari penelitian ini adalah petani dan pedagang manggis di
KecamatanTembilahan Hulu

Kabupaten Indragiri Hilir.

Data primer yang diambil meliputi identitas petani (umur, pendidikan, pengalaman usahatani, jumlah tanggungan keluarga), biaya, pendapatan.

2. Data sekunder

Data sekunder adalah yang diperoleh dari instansi yang berhubungan dengan penelitian ini yaitu Dinas Tanaman Panagan dan Holtikultura dan Badan Pusat Statistik.

\subsection{Metode Penentuan Sampel}

Metode yang digunakan untuk menentukan sampel petani manggis adalah metode random sampling (acak sederhana), yaitu sebuah bentuk metode sampel yang diambil sedemikian rupa sehingga tiap unit penelitian atau satuan elemen dari populasi mempunyai kesempatan yang sama untuk dipilih menjadi sampel menurut (Singarimbundan Effendi 2008). Jumlah populasi petani manggis yang ada di Kecamatan Tembilahan Hulu adalah sebanyak 54 orang. Untuk sampel yang diambil dari petani manggis di Kecamatan Tembilahan Hulu adalah sebanyak 20 orang.

Sedangkan untuk menentukan sampel pedagang pengumpul sekaligus pedagang pengecer buah manggis adalah dengan menggunakan metode snowball sampling (bola salju), yaitu dengan menemui beberapa orang pedagang manggis untuk menunjuk sampel berikutnya yang sesuai dengan karakteristik yang dibutuhkan dalam penelitian ini. Jumlah sampel yang diambil dari pedagang pengumpul yang sekaligus pedagang pengecer adalah 
sebanyak 5 orang sedangkan untuk jumlah sampel pedagang pengencer yang digunakan adalah sebanyak 10 orang.

\subsection{Metode Analisis Data}

\subsubsection{Analisis Marjin Pemasaran}

Marjin pemasaran merupakan perbedaan harga yang terjadi di tingkat petani sebagai produsen dengan harga ditingkat pedagang pengecer. Perhitungan analisis marjin pemasaran dilakukan untuk mengetahui perbedaan harga persatuan di tingkat petani atau tingkat konsumen yang terjadi pada tiap rantai pemasaran.

Menurut Azzaino, (1981) secara sistematis marjin pemasaran dapat dirumuskan sebagai berikut :

Dimana :

$$
\mathbf{M P}=\mathbf{P r}-\mathbf{P f}
$$

$$
\begin{aligned}
\mathrm{MP}= & \text { Marjin Pemasaran } \\
\mathrm{Pr}= & \text { Harga Ditingkat Pedagang } \\
& \text { Pengecer (retailer }) \\
\mathrm{Pf}= & \text { Harga Ditingkat Petani } \\
& (\text { farmer })
\end{aligned}
$$

\subsubsection{Analisis Farmer's Share}

Besarnya bagain haraga bagi petani dari harga jual dapat digunakan rumus sebagaiberikut :

$$
\mathrm{Si}=\frac{P f}{P r} X 100 \%
$$

Dimana :

$\mathrm{Si}=$ Persentase yang diterima petani

Pf $=$ Harga di tingkat konsumen

$\operatorname{Pr}=$ Harga di tingkat petani Besarnya bagian biaya untuk setiap pedagang dihitung dengan rumus (Azzaino,1981):

Sbi $=\frac{B i}{P r-P f} X 100 \%$
Dimana :

$$
\begin{aligned}
\text { Sbi }= & \text { Besarnya Bagian Biaya } \\
& \text { Setiap Pedagang ke-i } \\
\mathrm{Bi}= & \text { Biaya Pada Setiap Pedagang } \\
& \text { ke-i } \\
\mathrm{Pr}= & \text { Harga Ditingkat Petani } \\
\mathrm{Pf}= & \text { Harga Ditingkat Pedagang } \\
& \text { Pengumpul } \\
\mathrm{SKPi}= & \text { Besarnya bagian keuntungan } \\
& \text { setiap pedagang ke-i } \\
\mathrm{Ki}= & \text { Keuntungan pada setiap } \\
& \text { pedagang ke- } \mathrm{i}
\end{aligned}
$$

\subsubsection{Profit Marjin}

Profit margin digunakan untuk mengetahui berapa besar persentase laba bersih dari keseluruhan penjualan masingmasing pedagang di setiap saluran dan mengukur rentabilitas usaha tersebut. Besarnya profit margin dihitung dengan menggunakan rumus sebagai berikut (Winardi, 1989)

$$
P M=\frac{\text { Laba bersih }}{\text { Nilai Penjualan }} X 100 \%
$$

\subsubsection{Efisiensi Pemasaran}

Efisiensi pemasaran bisa dihitung dengan rumus :

$$
E P=\frac{T B}{T N P} X 100 \%
$$

Dimana :

$\mathrm{Ep}=$ Efisiensi Pemasaran

$\mathrm{TB}=$ Total Biaya Pemasaran

$\mathrm{TNP}=$ Total Nilai Produk, yaitu harga beli pada kosumen akhir.

Dari rumus ini berarti setiap penambahan biaya pemasaran dan semakin kecil nilai produk yang dijual memberikan arti bahwa hal ini menyebabkan adanya pemasaran yang tidak efisien. Sehingga apabila nilai Ep semakin kecil maka makin efisien pemasarannya. 


\section{HASIL DAN PEMBAHASAN Analisis Pemasaran}

Pemasaran dalam analisis pemasaran buah manggis di
Kecamatan Tembilahan Hulu diantaranya analisis margin pemasaran, farmer's share, keuntungan, profit margin dan efisiensi pemasaran tersaji pada tabel 1.

Tabel 1. Analsis Pemasaran Buah Manggis di Kecamatan Tembialahan Hulu Kabupaten Indragiri Hilir.

\begin{tabular}{|c|c|c|c|c|c|c|c|}
\hline \multirow[t]{2}{*}{ No } & \multirow[t]{2}{*}{ Uraian } & \multicolumn{6}{|c|}{ Pola Pemasaran } \\
\hline & & $\begin{array}{l}\text { Saluran } \\
\text { I }\end{array}$ & $(\%)$ & $\begin{array}{l}\text { Saluran } \\
\text { II }\end{array}$ & $(\%)$ & $\begin{array}{l}\text { Saluran } \\
\text { III }\end{array}$ & $(\%)$ \\
\hline A. & Farmer's Share & $9,700.00$ & 100.00 & $5,400.00$ & 37.50 & $5,300.00$ & 22.80 \\
\hline B. & Petani & & & & & & \\
\hline 1. & Harga Jual & $12,900.0$ & 3.26 & & & & \\
\hline 2. & Biaya Penyusutan & 0 & 2.13 & & & & \\
\hline 3. & Biaya Lain-lain & 420.02 & 5.39 & & & & \\
\hline 4. & Jumlah Biaya & 274.90 & & & & & \\
\hline 5. & Keuntungan & 694.92 & & & & & \\
\hline 6. & Margin Pemasaran & - & & & & & \\
\hline 7. & Profit Margin & - & & & & & \\
\hline & & - & & & & & \\
\hline C. & Pedagang Pengumpul & & & & & & \\
\hline 1. & Harga Beli & & & & & $5,300.00$ & \\
\hline 2. & Harga Jual & & & & & $9,400.00$ & \\
\hline 3. & Biaya Penyusutan & & & & & 345.89 & 3.68 \\
\hline 4. & Biaya Retribusi & & & & & 506.80 & 5.39 \\
\hline 5. & Biaya Lain-lain & & & & & 109.04 & 1.16 \\
\hline 6. & Jumlah Biaya & & & & & 961.72 & 10.23 \\
\hline 7. & Keuntungan & & & & & $3,138.00$ & 33.39 \\
\hline 8. & Margin Pemasaran & & & & & $4,100.00$ & 43.62 \\
\hline 9. & Profit Margin & & & & & & 89.77 \\
\hline D. & Pedagang Pengecer & & & & & & \\
\hline 1. & Harga Beli & & & $5,400.00$ & & $9,500.00$ & \\
\hline 2. & Harga Jual & & & $14,400.00$ & & $23,750.00$ & \\
\hline 3. & Biaya Pengangkutan & & & - & & 100.00 & 0.42 \\
\hline 4. & Biaya Transportasi & & & - & & 630.98 & 2.66 \\
\hline 5. & Biaya Penyusutan & & & 390.77 & 2.71 & 424.40 & 1.79 \\
\hline 6. & Biaya Retribusi & & & 522.33 & 3.62 & 551.38 & 2.32 \\
\hline 7. & Biaya Lain-lain & & & 140.60 & 0.97 & 205.43 & 0.86 \\
\hline 8. & Jumlah Biaya & & & $1,053.70$ & 7.31 & $1,837.19$ & 7.74 \\
\hline 9. & Keuntungan & & & $7,946.30$ & 55.18 & $11,913.00$ & 50.16 \\
\hline 10. & Margin Pemasaran & & & $9,000.00$ & 62.5 & $13,750.00$ & 57.89 \\
\hline 11. & Profit Margin & & & & 92.68 & & 92.09 \\
\hline E. & $\begin{array}{l}\text { Total Biaya } \\
\text { Pemasaran }\end{array}$ & 694.92 & & $1,053.70$ & & $2,798.18$ & \\
\hline F. & Total Margin & - & & $9,000.00$ & & $17,850.00$ & \\
\hline G. & $\begin{array}{l}\text { Keuntungan } \\
\text { Pemasaran } \\
\end{array}$ & & & $7,946.30$ & & 15.051 .19 & \\
\hline H. & Profit Margin & & & 92.68 & & & \\
\hline I. & Efisiensi & 5.39 & & 7.32 & & 7.90 & \\
\hline
\end{tabular}




\subsection{Saluran Pemasaran Buah Manggis}

Saluran pemasaran buah manggis yaitu melibatkan beberapa lembaga pemasaran yang menyalurkan buah manggis dari petani yang ada di Kecamatan Tembilahan Hulu sampai pada pedagang pengecer yang ada di Batam dan Jambi. Dari hasil penelitian dapat diketahui bahwa lembaga-lemabag pemasaran yang berperan dalam pemasaran buah manggis adalah petani, pedagang pengumpul dan pedagang pengecer. Di daerah penelitian terdapat 3 bentuk saluran pemasaran.

\section{Saluran Pemasaran I}

Pada saluran I Pemasaran buah manggis di Kecamatan Tembilahan Hulu Kabupaten Indragiri Hilir dapat digambarkan skemanya seperti pada gambar 1 berikut

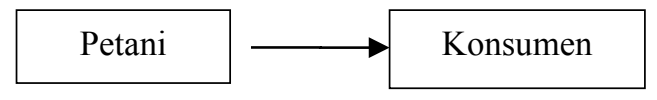

Petani manggis di saluran I ini langsung menjual hasil produksinya ke konsumen yang ada di Kecamatan Tembilahan Hulu, dengan harga jual rata-rata sebesar Rp. 9,500.00 per Kg.

\section{Saluran Pemasaran II}

Pada saluran II Pemasaran buah manggis di Kecamatan Tembilahan Hulu Kabupaten Indragiri Hilir dapat digambarkan skemanya seperti pada gambar 2 berikut

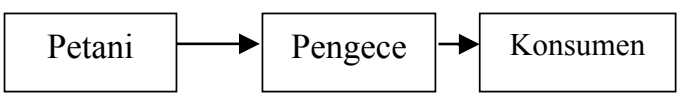

Pada saluran II Petani manggis di Kecamatan Tembilahan
Hulu menjual buahnya dengan mengantar langsung buah manggis ke pedagang pengecer yang berada di Kecamatan Tembilahan Hulu. Ratarata harga beli dari perati yaitu sebesar Rp.5,400.00 per Kg. Sedangkan harga jual buah manggis di tingkat pengecer adalah rata-rata sebesar Rp. 14,400.00 per kg.

\section{Saluran Pemasaran III}

Pada saluran III Pemasaran buah manggis di Kecamatan Tembilahan Hulu Kabupaten Indragiri Hilir dapat digambarkan skemanya seperti pada gambar 3 .

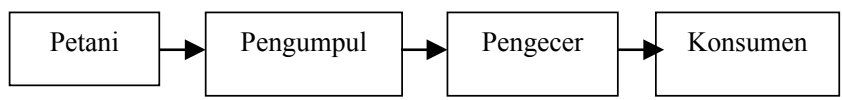

Pada saluran pemasaran III ini pedagang pengumpul yang sekaligus menjadi pedagang pengecer di Kecamatan Tembilahan Hulu menjual buah manggis ke pedagang pengencer yang berasal di Batam dan Jambi, yaitu dengan cara mendatangi langsung ke pedagang pengumpul yang ada di Kecamatan Tembilahan Hulu.

Harga beli buah manggis dari petani yaitu rata-rata sebesar Rp.5,300.00 per $\mathrm{Kg}$, dan harga yang di jual oleh pedagang pengumpul di Kecamatan Tembilahan Hulu adalah rata-rata sebesar 9,400.00 per $\mathrm{kg}$, sedangkan harga jual di tingkat pengencer yang berasal dari daerah Batam dan Jambi adalah rata-rata sebesar Rp. 23,250.00 per kg.

\subsection{Margin Pemasaran}

Tabel 1 menunjukan bahwa pada saluran I tidak terdapat margin pemasaran karena lembaga pemasaran pada saluran I adalah petani manggis itu sendiri. Disini 
petani tersebut langsung menjual hasil panen buahnya sendiri ke pasar sehingga tidak terdapat perbedaan atau selisih harga yang dibayar konsumen akhir dengan harga yang diterima oleh petani. Lembaga pemasaran di saluran II adalah pedagang pengecer. Besarnya marjin pemasran di saluran II adalah sebesar Rp.9,000.00 per $\mathrm{Kg}$ atau 64.28 persen dari harga jual rata-rata tingkat konsumen sebesar Rp. $14,400.00$ per Kg. Data perhitungan marjin pemasaran dapat dilihat pada lampiran 4 dan 5 . Lembaga pemasaran pada saluran III adalah pedagang pengumpul dan pedagang pengecer marjin pemasaran pada pemasran III sebesar Rp.18,016.67 per $\mathrm{Kg}$ atau 77,49 persen dari harga jual rata-rata di tingkat konsumen yaitu sebesar Rp. 23,250.00 per $\mathrm{Kg}$. Konsumen akhir di saluran ini yaitu konsumen buah manggis yang ada di daerah Batam dan Jambi.

Proses distribusi barang dari produsen ke konsumen akan menimbulkan berbagai resiko bagi lembaga pemasaran. Resiko lembaga pemasaran umumnya dinotasikan dalam biaya pemasaran. Biaya pemasaran buah manggis di Kecamatan Tembilahan Hulu Kabupaten Indragiri Hilir terdiri dari biaya pengangkutan, penyusutan transportasi dan biaya lain-lain. Biaya pengankutan berhubungan dengan upah buruh angkut, biaya penyusutan berkenaan dengan resiko berat buah manggis. Biaya transportasi berkaitan dengan penggunaan bahan bakar dan upah supir, dan biaya lalin-lain berkaitan dengan biaya retribusi dan biaya tak terduga yang lainnya yang sering muncul dalam proses distribusi.

\subsection{Farmer's Share}

Margin pemasaran dapat digunakan untuk mengetahui bagian harga untuk petani (Farmer's Share). Besarnya margin pemasaran dipengaruhi besarnya bagian biaya dan keuntungan lembaga pemasaran. Berdasarkan tabel 1 menunjukan bahwa farmer's share terbesar terdapat pada saluran I yaitu sebesar 100.00 persen. Pada saluran II yaitu sebesar 37.50 persen dari harga jual rata-rata di tingkat konsumen. Sedangkan pada saluran III besarnya farmer's share adalah 22.80 persen dari harga jual rata-rata tingkat konsumen.

Berdasarkan hasil penelitian pemasaran buah manggis di Kecamatan Tembilahan Hulu Kabupaten Indragiri Hilir menunjukan bahwa saluran pemasaran paling efisien berdasarkan besarnya farmer's share adalah saluran peamsaran I karena disini petani buah manggis itu sendiri yang melakukan kegiatan pemasaran.

\subsection{Profit Marjin}

Laba bersih masing-masing lembaga pemasaran di setiap saluran dapat menjadi indikator untuk mengukur rentabilitas suatu usaha. Indikator tersebut dinamakan dengan profit marjin.

Tabel 1 menunjukan bahwa profit marjin terbesar pada pedagang pengencer di saluran II yaitu sebesar 92.68 persen dari total penjualan. Pedagang pengencer di saluran II membeli buah manggis dengan harga yang relatif murah dan menjualnya ke konsumen dengan harga pasar yang relatif tinggi. Kondisi tersebut memberikan keuntungan bersih lebih besar bagi pedagang pengencer di setiap saluran, terutama saluran II 
dengan persentase keuntungan paling besar diantara tiga saluran.

\subsection{Efisiensi Pemasaran}

Efisiensi pemasaran dapat dihitung dengan rasio biaya pemasaran dibagi dengan nilai produksi yang di pasarkan, kemuidan dikalikan dengan 100 persen dan ini disebut dengan Ep. Makin kecil Ep semakin efisiensi pemasaran itu. Dari uraian sebelumnya telah diperoleh angka biaya pemasaran dan nilai produksi serta efisiensi pemasaran.

Dari tabel 1 dapat dilihat bahwa saluran pemasaran yang paling efisien terdapat pada saluran I dengan Ep 5.39 persen. Nilai indeks efisiensi sebesar 5.39 berarti setiap pengeluaran biaya pemasaran sebesar Rp. 1,000.00 maka petani akan mendapatkan keuntungan sebesar Rp.5,039.00. kemudian diikuti dengan saluran II dengan Ep sebesar 7.32 persen.

Pada saluran I persentase biaya yang dikelurkan relatif kecil apabila dibandingkan dengan saluran pemasaran lainnya disebabkan karena saluran I dalam pemasaran buah manggis di Kecamatan Tembilahan Hulu Kabupaten Indarigi Hilir tidak melibatkan lembaga pemasaran, yang berperan dalam memasarkan hasil panen buah manggis tersebut adalah petani itu sendiri. Dan pada saluran I posisi tawar petani lebih kuat dibandingkan dengan saluran pemasaran lainnya karena petani itu sendiri yang menjual hasil panennya ke konsumen sehingga harga jual buah manggis yang diterima oleh petani lebih tinggi.

\section{KESIMPULAN DAN SARAN}

\subsection{Kesimpulan}

1. Saluran pemasaran buah manggis di Kecamatan Tembilahan Hulu Kabupaten Indragiri Hilir yaitu saluran I petani-konsumen, saluran II petani - pedagang pengecerkonsumen dan saluran III petani - pedagang pengumpul pedagang pengecer - konsumen.

2. Hasil analisis margin pemasaran, farmer's share dan profit margin margin adalah sebagai berikut :

a. Pada saluran I tidak terdapat margin pemasaran. Besarnya margin pemasaran pada saluran II adalah sebesar Rp. 9,000.00 per $\mathrm{Kg}$ dan pada saluran III adalah sebesar Rp.18,016.67 per Kg.

b. Farmer's Share pada saluran I adalah sebesar 100.00 persen dan pada saluran II adalah $37.50 \quad$ persen sedangkan pada saluran III besarnya farmer's share adalah 22.80 persen.

c. Profit marjin terbesar pada pedagang pengencer di saluran II yaitu sebesar 92.68 persen, kemudian diikuti dengan pedagagang pengencer pada saluran III yaitu sebesar 92.09 persen sedangkan profit marjin yang diperoleh oleh pedagang pengumpul pada saluran III yaitu sebesar 89.77 persen.

3. Saluran I merupakan saluran pemasaran yang paling efisien dengan Ep 5.39 persen kemudian diikuti dengan saluran II dengan Ep sebesar 7.32 persen dan efisiensi pada saluran III yaitu sebesar 7.90 persen 


\subsection{Saran}

1. Petani disarankan menjual langsung buah manggis ke konsumen tanpa melalui lembaga pemasaran sehingga harga buah manggis menjadi lebih tinggi dan keuntungan petani lebih tingggi.

2. Perlu pengembangan media informasi harga sampai tingkat petani, misalnya melalui penyuluh pertanian. Informasi harga diharapkan dapat membantu petani dalam merencankan dan menetukan harga buah manggis

\section{DAFTAR PUSTAKA}

Arifin, B, A., Hudoyo,dan A. Amron. 1997. PengembanganPemasaran BuahBuahanIndonesia.Jurnalsos ioekonomika.Vol3 No 6 Desember 1997.FakultasPertanianUni versitasLampung.

Azzaino,Z.1987.PengantarTataniag a

Pertanian.DepartemenIlmu -ilmu Sosial Ekonomi Pertanian.Fakultas Pertanian IPB.Bogor.

Balai Penelitian Tanaman Buah. 2006. Aspek Tanaman Holtikultura.

Tropika.Solok.
Dinas Tanaman Pangan dan Holtikultura Kabupaten Indragiri Hilir 2016.

Endah,Y.L. 2006. Efisiensi Pemasaran Jeruk Siamdi Kecamatan Bukateja Kabupaten Purbalingga.Skripsi.Fakult as Pertanian,Universitas Jenderal Soedirman,Purwokerto.64 hal.

Kohls,R.L. and J.N.Uhl..1979.Marketing of Agricultural Products. Macmillan.NewYork.168h al.

Kotler,

P. 1992.

ManajemenPemasaran :Analisis, PerencanaandanPengendali an. Erlangga.Jakarta

Limbong dan Sitorus 1995 Konsep Margin Pemasaran

Pernama.A.W.,2010 Kulit buah manggis dapat Menjadi minuman Instan Kaya Antioksidan, Warta Litbang Deptan, 23(2);3.

Mubyarto. 1979. PengantarEkonomiPertania n. LP3S. Yogyakarta. 